\title{
Visceral Examination
}

National Cancer Institute

\section{Source}

National Cancer Institute. Visceral Examination. NCI Thesaurus. Code C124599.

An assessment of the internal soft tissue structures. 